\title{
Lean Hospital Approach to Identify Critical Waste in the Outpatient Pharmacy Instalation of RSI PKU Muhammadiyah Pekajangan
}

\section{Lusi Rahmani Putri*, Susanto}

* Penulis Korespondensi: lusiputri@yahoo.com

Pascasarjana Universitas Muhammadiyah Yogyakarta Kasihan, Bantul, DIY, Indonesia

\begin{tabular}{l}
\hline $\boldsymbol{I} \boldsymbol{N D}$ EXI $\boldsymbol{N} \boldsymbol{G}$ \\
\hline Keywords: \\
Lean Hospital; \\
Outpatient Pharmacy; \\
Waste Motion;
\end{tabular}

\begin{abstract}
A B S T R A C T
This Research Purpose to identify critical waste, root cause of critical waste, up to giving recommended improvement to minimize critical waste in the outpatient pharmacy. This research uses qualitative approach with case study design. The health service process is visualized with value stream mapping, the amount of critical waste is obtained by distributing questionnaires, while the root cause of critical waste is acquired by 5 why method of interview. The recommended improvementis accomplished by discussion between team and expert panel. Based on the value stream mapping, it has obtained $16,67 \%$ of ratio value added to waste for non concoction prescription and $14.52 \%$ of ratio value added to waste for concoction prescription. Based on waste questionnaire distribution, motion got the highest rank as the most often exist waste with 19\% percentage. The root causes of this motion waste is nonexistence of a routine schedule on the work space organization, which affecting the effectiveness of pharmacy staff to complete their task. The recommended improvement to minimize this waste motion is to conduct 5 S method.
\end{abstract}

Kata kunci:

Lean Hospital;

Instalasi Farmasi Rawat-

Jalan;

Waste Motion;

\begin{abstract}
Penelitian ini bertujuan ntuk mengidentifikasi waste kritis, akar penyebab waste kritis hingga memberikan usulan perbaikan untuk meminimalkan waste kritis di Instalasi Farmasi Rawat Jalan RSI PKU Muhammadiyah Pekajangan. Penelitian ini menggunakan pendekatan kualitatif dengan desain studi kasus. Gambaran proses pelayanan dipetakan melalui value stream mapping, penetepan waste kritis diperoleh melalui penyebaran kuesioner, akar penyebab waste kritis diperoleh melalui wawancara mendalam dengan metode 5 why. Usulan perbaikan didapatkan melalui diskusi tim dan expert panel. Berdasarkan pemetaan value stream mapping didapatkan VAR untuk resep non racikan sebesar 16,67 \%, sedangkan untuk resep racikan sebesar 14,52\%. Keberadaan waste Motion menduduki peringkat tertinggi dengan persentase sebesar $19 \%$. Akar penyebab dari waste motion adalah tidak adanya standar terkait pengorganisasian tempat kerja yang berdampak pada efektifitas pemberi pelayanan dalam menyelesaikan tugasnya. Usulan perbaikan untuk akar penyebab waste kritis ini adalah dengan menerapakan metode $5 \mathrm{~S}$.
\end{abstract}

(C) 2017 JMMR All rights reserved

\section{INTRODUCTION}

It is a must for hospitals to always provide effective health service according to the standard of hospital service. One of the ways for the government to maintain the quality and standard of hospital service is through accreditation. With that regulation, every hospital in Indonesia keeps on competing to evaluate and to improve the productivity and quality of service, moreover with the existence of BPJS health system which officially operates since 1 January 2014 and actively develops systems of quality control and cost control. The ability to give effective and efficient health service to stakeholders in all hospital installations has become a requirement, particularly in pharmacy.

Pharmacy is one of health service terminals which directly deals with society, and it is required to be able to fulfil people's need for medicines thoroughly according to the code of Ethics and standard of service. According to the Department of Health of Republic of Indonesia, nowadays there are many reports on problems which occur in outpatient pharmacy. It indicates some amount of waste in outpatient pharmacy which affects stakeholders' satisfaction. Waste is all kinds of activities which do not reflect help in patients' process of recovery. All waste must be eliminated or minimized not only to increase patients and employees safety, but also to boost patients satisfaction and to decrease hospital cost.

Various concepts have been proposed to overcome inefficiency in health service, and one of the concepts is lean. Lean is a continuous effort to eliminate waste and increase added value of products in the form of goods and service, in 
order to give values to customers.

Lean concept was initiated by Toyota, then it was followed by heads of health service. Lean was adopted as a systematic approach to improve quality and efficiency. Lean application was reported to give effect of change on health service with dramatic achievement in quality, safety, and efficiency.

RSI PKU Muhammadiyah Pekajangan is one of the hospitals in Pekalongan, Central Java which continues to develop. This type $\mathrm{C}$ hospital has been serious in preparing hospital accreditation. Every installation in the hospital keeps on evaluating and improving, including the outpatient pharmacy because this installation has a key role in giving service to end-customer and for business aspect of hospital. Pharmacy management continues to look for various methods which are appropriate to be implemented there in order to improve quality of service. So far, the management has never made improvement of service quality using lean hospital approach.

That background drives the researcher to conduct a research entitled " Lean Hospital Approach to Identify Critical Waste in the Outpatient Pharmacy Installation of RSI PKU Muhammadiyah Pekajangan". The problems of this research are formulated as follows:

1. What makes the critical waste in the Outpatient Pharmacy Installation of RSI PKU Muhammadiyah Pekajangan?

2. What are the root causes of critical waste in the Outpatient Pharmacy Installation of RSI PKU Muhammadiyah Pekajangan?

3. What improvement is proposed using lean hospital approach to minimize critical waste in the Outpatient Pharmacy Installation of RSI PKU Muhammadiyah Pekajangan?

\section{RESEARCH METHOD}

This research employs qualitative approach designed with case study. Qualitative approach is a process of research and comprehension based on methodology which investigates a social phenomenon and human problem. The data collection technique was conducted in natural setting. Mostly, the data collection technique was done using questionnaire, participative observation,in-depth interview, unstructured interview, and documentation or documentation study. Questionnaire was used to identify waste in the Outpatient Pharmacy Installation of RSI PKU Muhammadiyah of Pekajangan.

The distribution of questionnaire was conducted by the researcher during non-service hours and the researcher always assisted the participants when filling out the items of the questionnaire to ensure that they were not misdirected. Participative observation is observation in which the researcher observed what people did, listened to what they said, and participated in the activities being studied. The researcher chose participative observation because this observation requires the researcher to be directly involved in the activities being studied. Active participation was done so that during the observation the researcher also did what the sourceperson or informant did, although it was not done thoroughly.

Observation was conducted by directly observing the process of giving service in the Outpatient Pharmacy Installation of RSI PKU Muhammadiyah Pekajangan, from the time patients arrived until they got service. Observation was also carried out through a description of the service system.

In-depth interview was conducted to get information that had not been obtained or thoroughly informed to the researcher. In-depth interviews were conducted to some informants or participants who have various structural levels of management and they were aimed for triangulation in order to get objectivity of interview results of the informants. In in-depth interviews, every informant or participant had to ask question which was in accordance with their structural level and field of competence.

In-depth interview belongs to structured interview because the focus of information needed by the researcher had been recognized, which was the root of the problem of critical waste occuring in the Outpatient Pharmacy Installation of RSI PKU Muhammadiyah Pekajangan. The interview questions were arranged using five whys method.

Unstructured interview is a free interview, in which information about development and observation to the informant is spontaneously obtained. The researcher had not known the exact data that would be gained through this kind of interview. Unstructured or open interview interview usually takes place during observation. Documentation is made in every stage of research and it might be in form of a recorded interview, pictures, notes, and so on, all of which support the obtained data. The result of interviews with informants are also used as an alternative solution or problem solving proposed by the researcher.

Documents study which is conducted by recording documents of supporting data which are needed and available in hospital is called secondary data. Secondary data consist of the flow of patients process and other 
stakeholders, standard operating procedure of service, map of Outpatient Pharmacy Installation of RSI PKU Muhammadiyah Pekajangan, and other data from RSI PKU Muhammadiyah Pekajangan which are related to the research.

Those ways are taken as triangulation for the purpose of gaining data objectivity, knowing data convergence, and finding data inconsistency or contraindication. The researcher will obtain consistent, complete, and definite data through triangulation. In addition, it will also increase the strenght of data when compared with a particular approach.

After observation and data collection, the data will be processed through the following stages:

\section{Mapping the service system in the Outpatient Pharmacy Installation of RSI PKU Muhammadiyah Pekajangan}

The purpose of mapping the service system is to find out the current process in the Outpatient Pharmacy Installation of RSI PKU Muhammadiyah Pekajangan. This mapping is intended to portray every type of business activity starting from the process of service in the Outpatient Pharmacy Installation of RSI PKU Muhammadiyah Pekajangan, who the stakeholders are, who is in charge, and how the process of service flows.

In this stage, data were obtained from active and participative observation directly in the field by following, practicing, and observing the process of service activity. In addition, the researcher conducted unstructured interview during the process of participative observation to get data by improvisation, studied the documents needed, and made documentation. The analysis stages of the mapping system in the Outpatient Pharmacy Installation of RSI PKU Muhammadiyah Pekajangan resulted in current value stream mapping of the service system and the service process flow.

\section{Identifying the service process}

After the value stream mapping, the researcher identified activities in that organization into two activities - value added activities and non value added activities. Information was obtained from observation, unstructured interview both qualitatitively and quantitatively, documents study, and documentation. Then, the researcher calculated ratio value added activities to waste to distribute the performance of service system in numbers which show the level of research scale in percentage.

Identifying critical waste of the service process in the Outpatient Pharmacy Installation of RSI PKU Muhammadiyah Pekajangan

In this stage, waste of the service process was identified in the Outpatient Pharmacy Installation of RSI PKU Muhammadiyah Pekajangan by distributing questionnaire. The purpose is to find out the level of frequency of eight kinds of waste according to lean concept which happens according to observation and the employees' experience. The questionnaire was analyzed using BORDA method, then the type of waste with the highest level was determined as critical waste.

\section{Finding the root of the problem of critical waste}

After determing the type of critical waste in the service process, the researcher identified the root of cause through in-depth interviews to the selected informants using 5 why method.

\section{Gathering improvement ideas}

This stage is aimed at getting improvement ideas which are adjusted to the need, ability, and the existing resource as the manifestation of improvement.Gathering improvement ideas was done through discussions with team and panel experts. This method was used in order to get inputs and suggestions from experts of lean hospital. When it was hard to do, discussion was only held personally between the researcher and the expert.

\section{Designing improvement ideas}

Improvement ideas which were proposed consisted of map, setting, layout, process simplification, proposal of method for work process, improvement on visual management, flow of service process and other resources that contribute to management efficiency in the Outpatient Pharmacy Installation of RSI PKU Muhammadiyah Pekajangan and eliminate unnecessary waste to incerase the value of service.

\section{Drawing conclusion and recommendation}

Conclusion is made based on the analysis result and proposed improvement. Recommendation is made based on 
the objective of the research which is stated in the introduction section, and generally intended for the improvement of service process and specifically to identify the produced waste, to know the critical waste, and to propose for improvement in order to increase the value of service in the Outpatient Pharmacy Installation of RSI PKU Muhammadiyah Pekajangan.

Figure 1. Value Stream Mapping of Non-Concoction Prescription Service

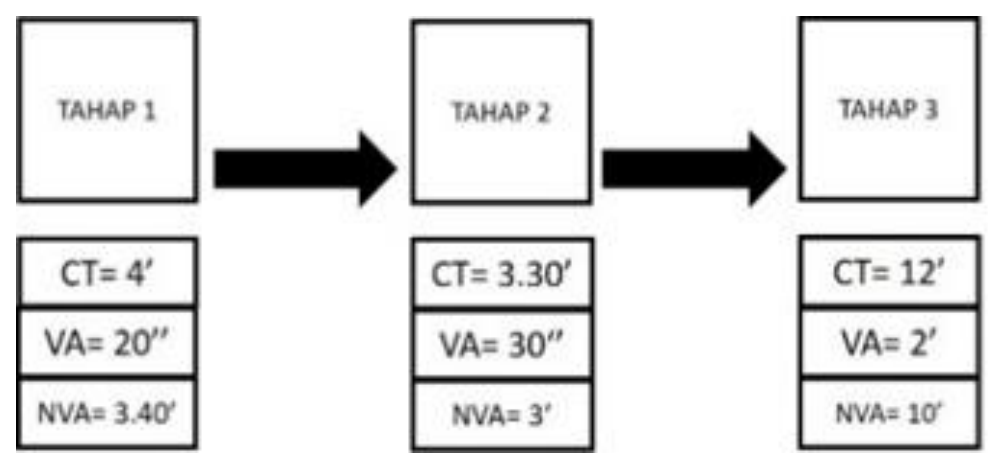

Figure 2. Value Stream Mapping of Concoction Prescription Service

\section{RESULT AND DISCUSSION}

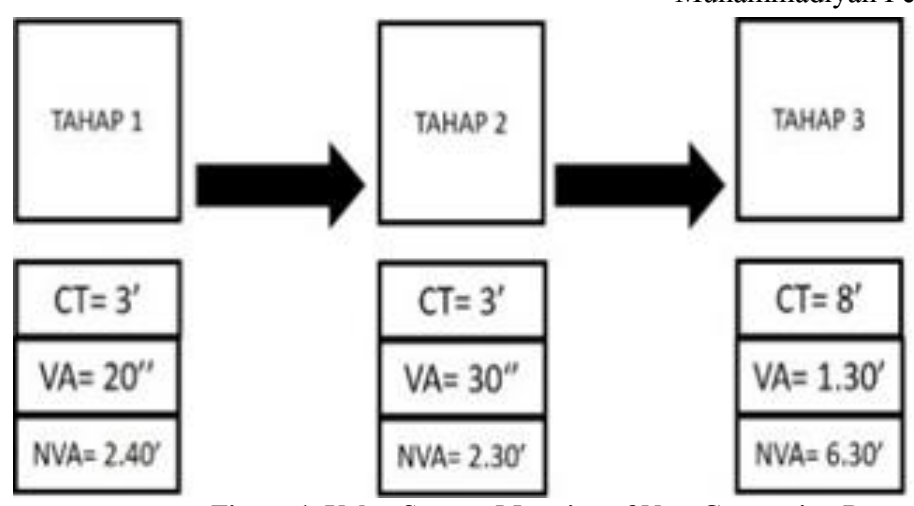

Value Stream Mapping dan Value Added Assesment The Process of Outpatient Pharmacy Service of RSI PKU Muhammadiyah Pekajangan

VSM is a description of the service activities since the service is requested by the patients (customer) until it is fulfilled. The fixing of value stream mapping (VSM) will help the researcher to recognize the activities in the existing service process that he is able to value the activities compositions of value added and non-value added during the service process (Value Added Assesment).

The results of value stream mapping and value added assesments mapping results during the service process in the Outpatient Pharmacy Installation of RSI PKU Muhammadiyah Pekajangan are as follows:

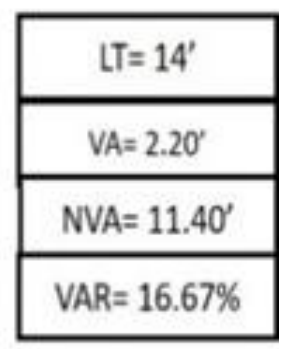

$\operatorname{VAR}=16.67 \%$
$\mathrm{CT}$ is an abbreviation from cycle time, VA is value adding time, NVA is non value adding time, VAR is value added ratio and $\mathrm{LT}$ is lead time.

Critical waste in the service process in the Outpatient Pharmacy Installation of RSI PKU Muhammadiyah Pekajangan.
Before determining the critical waste out of the 8 existing wastes, the researcher conducted observations and interviews to identify the 8 wastes during the service process in the Outpatient Pharmacy Installation of RSI PKU Muhammadiyah Pekajangan. The wastes identified during the service process in the Outpatient Pharmacy Installation are as follows: 
a. Defects, it covers the errors in etiquette labeling, the giving of pharmaceutical preparation which is inappropriate with the dosage written in the patient's prescription due to similar packages.

b. Overproduction, it covers the pharmacy staffs who often prepare the frequent concoction medicine prescribed by doctors earlier before there is any requests for it.

c. Transportation, it covers the patients wandering for information of the next stages must be done since there is no clue or notification before.

d. Waiting, it covers the pharmacy staffs especially for those having morning shift when it is often free of any activities since the minimum doctors' schedule in the morning or the doctors' schedule that suddenly changes. These conditions make the patients wait for the pharmacy staff to do the administration study, medicine study, and medicine preparation.

e. Inventory, it covers the overabundant medicine supply that reaches its expiry dates. f. Motion, it covers the pharmacy staffs who cannot freely perform in completing some services due to the poor workspace organization.

g. Overprocessing, it covers the pharmacy staffs who must inform the patients especially BPJS patients since the doctors give some prescriptions which are not included in the national formulary (Fornas) or the prescriptions must be bought in other pharmacies.

h. Human potential, it covers the pharmacy staffs who tend to be passive in giving suggestions and comments in order to improve the service process both to the management or other health workers (such as doctors and polyclinic nurses) since they don't get enough responses from the concerned parties.

After identifying these 8 wastes, the researcher conducted the waste measurement of the most frequent waste or the critical waste in the service process in the Outpatient Pharmacy Installation of RSI PKU Muhammadiyah Pekajangan. The critical waste determination was done by distributing questionnaires and being processed with the BORDA method. The recapitulation results of waste questionnaires are as follows:

Table 1. Waste Questionnaires Recapitulation in the Outpatient Pharmacy Installation of RSI PKU Muhammadiyah Pekajangan

WASTE TYPE PERCENTAGE

\begin{tabular}{lc}
\hline DEFECT & $17 \%$ \\
OVERPRODUCTION & $5 \%$ \\
TRANSPORTATION & $10 \%$ \\
WAITING & $17 \%$ \\
INVENTORY & $8 \%$ \\
OVERPROCESSING & $19 \%$ \\
HUMAN POTENTIAL & $8 \%$ \\
SCORE & $100 \%$ \\
\hline
\end{tabular}

An analysis of the root causing critical waste in the service process in the Outpatient Pharmacy Installation of RSI PKU Muhammadiyah Pekajangan

The analysis of the root causing the critical waste is in the form of motion in the Outpatient Pharmacy Installation of RSI PKU Muhammadiyah Pekajangan. It was done by doing deep interview with the selected respondents using 
the 5-why method. The results of the deep interview with the selected respondents are summarized by the researcher in the following table:

Table 2. The Roots Causing the Critical Waste in the Outpatient Pharmacy Installation of RSI PKU Muhammadiyah Pekajangan

\begin{tabular}{|c|c|c|c|c|c|c|c|c|c|}
\hline \multicolumn{2}{|c|}{ WHY 1} & \multicolumn{2}{|c|}{ WHY 2} & \multicolumn{2}{|c|}{ WHY 3} & \multicolumn{2}{|c|}{ WHY 4} & \multicolumn{2}{|c|}{ WHY 5} \\
\hline Why? & Because & Why? & Because & Why? & Because & Why? & Because & Why? & Because \\
\hline $\begin{array}{l}\text { Why do } \\
\text { the } \\
\text { pharmacy } \\
\text { staffs take } \\
\text { a long } \\
\text { time to } \\
\text { prepare } \\
\text { patients' } \\
\text { me-dicine? }\end{array}$ & $\begin{array}{l}\text { Because the } \\
\text { access for } \\
\text { staffs to the } \\
\text { medicine } \\
\text { storage } \\
\text { room is } \\
\text { often } \\
\text { obstructed } \\
\text { causing the } \\
\text { pharmacy } \\
\text { staffs must } \\
\text { take turn to } \\
\text { get there. }\end{array}$ & $\begin{array}{l}\text { Why the } \\
\text { access } \\
\text { for staffs } \\
\text { to the } \\
\text { medicine } \\
\text { storage } \\
\text { room is } \\
\text { often } \\
\text { obstructe } \\
\text { d } \\
\text { causing } \\
\text { the } \\
\text { pharmac } \\
\text { y staffs } \\
\text { must } \\
\text { take turn } \\
\text { to get } \\
\text { there? }\end{array}$ & $\begin{array}{l}\text { Because the } \\
\text { track access } \\
\text { to the } \\
\text { medicine } \\
\text { storage room } \\
\text { is narrow so } \\
\text { as people } \\
\text { can only } \\
\text { pass it one } \\
\text { by one. }\end{array}$ & $\begin{array}{l}\text { Why is } \\
\text { the ac- } \\
\text { cess to } \\
\text { the me- } \\
\text { dicine } \\
\text { storage } \\
\text { room is } \\
\text { narrow } \\
\text { so as } \\
\text { people } \\
\text { can } \\
\text { only } \\
\text { pass it } \\
\text { one by } \\
\text { one? }\end{array}$ & $\begin{array}{l}\text { Because } \\
\text { some parts } \\
\text { of it are used } \\
\text { to put some } \\
\text { boxes of } \\
\text { pharmacy } \\
\text { tools stocks. }\end{array}$ & $\begin{array}{l}\text { Why } \\
\text { the } \\
\text { boxes } \\
\text { of } \\
\text { pharma } \\
\text { cy } \\
\text { stocks } \\
\text { are put } \\
\text { in the } \\
\text { access } \\
\text { that } \\
\text { they } \\
\text { cover } \\
\text { some } \\
\text { parts of } \\
\text { it? }\end{array}$ & $\begin{array}{l}\text { Because the } \\
\text { racks inside } \\
\text { the storage } \\
\text { room are } \\
\text { full with } \\
\text { the piles of } \\
\text { boxes with } \\
\text { medicine or } \\
\text { health tools } \\
\text { inside } \\
\text { them. Some } \\
\text { boxes are } \\
\text { full but } \\
\text { some are } \\
\text { half-empty } \\
\text { that are not } \\
\text { regularly } \\
\text { tidied up. }\end{array}$ & $\begin{array}{l}\text { Why } \\
\text { the } \\
\text { boxes } \\
\text { inside } \\
\text { the } \\
\text { storage } \\
\text { room } \\
\text { are not } \\
\text { regularl } \\
\text { y tidied } \\
\text { up? }\end{array}$ & $\begin{array}{l}\text { Because } \\
\text { there is no } \\
\text { regular } \\
\text { schedule or } \\
\text { standard set } \\
\text { related to the } \\
\text { organization } \\
\text { of this } \\
\text { workspace in } \\
\text { the } \\
\text { mentioned } \\
\text { installation. }\end{array}$ \\
\hline
\end{tabular}

The recommended improvement to minimize the critical waste in the service process in the Outpatient Pharmacy Installation of RSI PKU Muhammadiyah Pekajangan.

The recommended improvement to minimize the critical waste in the form of motion in the service process in the Outpatient Pharmacy Installation of RSI PKU Muhammadiyah Pekajangan is conducted by having team discussion and expert panel in which they understand the lean concept as the approach that is able to improve the service quality. In the discussion, the researcher will also consider that change and plan an idea in a hospital is not always easy because it relates to some policies, the current rules, and the authorities and the importance of having consultation with the applicable hospital management as well such as program planner and hospital suggestion.

From the discussion results conducted by the researcher, the team, and the experts to minimize the waste motion in the Outpatient Pharmacy Installation of RSI PKU Muhammadiyah Pekajangan, they agree that the recommended improvement can be done by implementing the $5 \mathrm{~S}$ method. This method is the workspace organization standard in this research which is the area of the Outpatient
Pharmacy Installation of RSI PKU Muhammadiyah Pekajangan

\section{Discussion}

Based on the result of value stream mapping in the Outpatient Pharmacy Installation of RSI PKU Muhammadiyah Pekajangan, it is found out that VAR intended for the patient service process with nonconcoction prescription is $16.67 \%$ while the VAR for the patient service process with concoction prescription is $14.52 \%$.

If the ratio value between waste and the total activity which is over than $30 \%$, the company cannot be considered as the lean one. ${ }^{4}$ It can be concluded that the service process in the Outpatient Pharmacy Installation of RSI PKU Muhammadiyah Pekajangan can be classified as not yet lean. It indicates that the activities causing the waste must be soon identified and eliminated for improving the service process efficiency and patients' satisfaction as the end customer.

Based on the waste questionnaires counting results processed using BORDA method, it is known that the 
motion becomes the critical waste or the most frequent waste occurring in the Outpatient Pharmacy Installation of RSI PKU Muhammadiyah Pekajangan since it is in the highest rank with the percentage of $19 \%$. Motion is a less effective activity or movement performed by the service giver that does not add the value and hamper the service process resulting at the long lead time. ${ }^{5}$

The less effective room layout, difficult-to-detect pharmaceuticals finding process, and the flow of unorganized service process often become the roots causing the waste performed by the service giver.

Motion is an important thing which is closely related with work efficiency. It is explained in a theory introduced by Frank and Lillian Gilbreth known as the theory of time and motion study in which they formulated 3 important points. The followings are the summary of the theory they are: ${ }^{6}$

1. To understand the completion of a task efficiently, a worker must focus on two factors which are motion and time.

2. Decrease the number of motion will increase efficiency in completing a task.

3. The aim of increasing the work efficiency is to increase the benefit and satisfaction for the workers.

Therefore, the existence of the waste motion existing in the Outpatient Pharmacy Installation of RSI PKU Muhammadiyah Pekajangan as the critical waste must be identified to find the roots causing it in order to eliminate or at least minimize the occurrence so as the workers work efficiency will increase.

Based on the interview done using the 5 Why method, it is found out in this research that the roots causing the critical waste are there is standard for workspace organization in the Outpatient Pharmacy Installation of RSI PKU Muhammadiyah Pekajangan. The pharmacy area which is not really large, the less effective room layout, and the poor workspace organization become a strongly threatening combination in giving the qualified service process since it has a significant influence toward the workers work efficiency.

Regarding these problem roots, the recommended improvement in this research is to implement the $5 \mathrm{~S}$ method in the Outpatient Pharmacy Installation of RSI PKU Muhammadiyah Pekajangan. This method is a basic concept which was previously developed in Japanese manufacture such as Toyota. It has succeeded in making the company work system become lean.
This method is reported as one of the excellent methods in the lean concept since it is known as a simple and easy to understand one. This method also reported as one of the most frequently used lean tool in healthcare. ${ }^{12}$ The keys of success for this method are discipline and consistency. In healthcare organization this method is directed towards improving efficiency, clinical outcomes or health status and financial performance. ${ }^{15}$

John touissant, a CEO of Thedacare Health System (Winconsin) predicts that the improvement using the $5 \mathrm{~S}$ method can decrease the number of the average time waste of a nurse having an 8-hours shift from 3.5 hours per day to only 1 hour per day. ${ }^{3}$

The $5 \mathrm{~S}$ method is a method focusing as the problem solving to handle the problems of workspace organization. Even though this method is originated from the manufacture industry, there have been many researches stating that this method can be implemented in health industry. This statement is in accordance with the research conducted in Hong Kong by Fanny Y.F Young in 2014 entitled "The Use of $5 S$ in Healthcare Services" which successfully proved that the $5 \mathrm{~S}$ method can be implemented in the health services and is able to give benefits. In this research, it is mentioned that the key of success for the $5 \mathrm{~S}$ method lies in the sustain stage. ${ }^{7}$

There are other researches proving the benefit of the $5 \mathrm{~S}$ method implementation such as a research conducted by Shogo Kanamori et.al. entitled "Implementation of $5 \mathrm{~S}$ Management Method for Lean Healthcare at Health Center in Senegal" in 2015 concluding that there is a service quality change which is the service becomes very efficient. The service focuses more on the patients including in increasing the patient safety and the improvement of the service givers' and health services customers' attitude and behavior in health facilities in Senegal including the $5 \mathrm{~S}$ implementation for a year. ${ }^{8}$

The success of $5 \mathrm{~S}$ implementation is also recorded in another research entitled "Survey To See The Impact Of $5 \mathrm{~s}$ Implementation Among Staff Of Kpj Seremban Specialist Hospital Malaysia” conducted by AR. Abdul Aziz et.al. in 2014 stating that there are an increase in work productivity, work quality, staff morality quality, work safety in the working area, the staff's commitment in maintaining the cleanliness, neatness, and the workspace comfort which are really felt by the staffs as the impact of the $5 \mathrm{~S}$ method implementation. ${ }^{9}$

Successfully $5 \mathrm{~S}$ method have been documented in a number of healthcare subjects in a range of departments from patient facilities to finance, laboratories, 
administration and offices. ${ }^{13}$ Presented results show that $5 \mathrm{~S}$ can be applied to healthcare services with beneficial effects such as cleaner, organized, efficient workplaces for enhanced safety and increased productivity, reduction of inventory and supply costs and recapturing of valuable spaces and minimizing. ${ }^{7,14}$

$5 \mathrm{~S}$ means that differentiating between things needed and not needed, taking a firm decision, implementing stratification management to omit things not needed and the causes of the decreasing work performance which previously causes the work productivity problems. ${ }^{10}$

Discussing about the $5 \mathrm{~S}$ method means that it also discusses about how someone is able to treat his workspace appropriately. If the workspace is well-arranged, clean, in orderly, and organized, then the individual's working ease can be created. With this ease obtained by each worker in the workspace, the industry main targets will be fulfilled. These main targets are work efficiency, work productivity, work quality, and work safety. The fulfillment of these main targets is the key for an industry to develop. ${ }^{11}$

In Japanese, 5S are Seiri, Seiton, Seiso, Seiketsu, and Shitsuke. In English, 5S are Short, Strore, Shine, Standarize, and Sustain. Meanwhile in Bahasa Indonesia, $5 \mathrm{~S}$ is also known as 5R which are Ringkas, Rapi, Resik, Rawat, and Rajin.

\section{CONCLUSION}

Based on the waste questionnaires counting results which is distributed to all parties giving the services in the Outpatient Pharmacy Installation of RSI PKU Muhammadiyah Pekajangan, it is determined that the recent critical waste is waste motion with the percentage of $19 \%$. Based on the interview results using the 5-why method to the selected respondents during the research, it is found that the roots causing critical waste (motion) in the Outpatient Pharmacy Installation of RSI PKU Muhammadiyah Pekajangan are there is no schedule or standard set related to the workspace organization. It affects the staff effectiveness as the service giver in completing the tasks. The recommended improvement with the lean hospital approach for the roots causing critical waste in the service process in the Outpatient Pharmacy Installation of RSI PKU Muhammadiyah Pekajangan is by implementing the $5 \mathrm{~S}$ method in which this method is a superior lean hospital method to reduce the waste by increasing the workspace organization.

\section{REFERENCES}

1. Humas Bpjs Kesehatan. (2013). Sejarah Perjalanan Jaminan Sosial Di Indonesia. Dipetik Juni 10, 2016, Dari Bpjs Kesehatan: Http://BpjsKesehatan.Go.Id/Bpjs/Index.Php/Pages/Detail/2013/4

2. Suciati, Susi Dan Adisasmito, Wiku B.B. (2006). Analisis Perencanaan Obat Berdasarkan Abc Indeks Kritis Di Instalasi Farmasi. Jurnal Manajemen Pelayanan Kesehatan. Vol. 9

3. Graban. (2009). Lean Hospital: Improving Quality, Patient Safety, And Employee Satisfication. Dipetik Juni 10, 2016, Dari Crc Press: Https://Www.Crcpress.Com/Lean-HospitalsImproving-Quality-Patient-Safety-And-EmployeeSatisfaction/Graban/P/Book/9781420083804

4. Gasperz. (2011). A Lean Six Sigma For Manufacturing and Service Industries. Dipetik Juni 10, 2016, Dari Http://Cdn.Intechopen.Com/Pdfs-Wm/31666.Pdf

5. Helmold, M. (2011). Driving Value in the Upstream Chain Management through Lean Principles. International Journal of Lean Thinking 2(2), 1-8

6. Laurel. (2017). Management Theory of Frank and Lillian Gilbreth. Dipetik Maret 12, 2017, Dari https://www.business.com/articles/ maagement-theoryof-frank-and-lillian- gilbreth/

7. Fanny Y. F. Young. (2014). The Use of $5 S$ in Healthcare Services: a Literature Review. Dipetik Maret 12, 2017, Dari http://ijbssnet.com/journals/Vol_5_No_10_1_Septembe r_2014/30.pdf

8. Kanamori, S. et al. (2015). Implementation of $5 S$ management method for lean healthcare at a health center in Senegal: a qualitative study of staff perception. Dipetik Maret 12, $2017 . \quad$ Dari https://www.ncbi.nlm.nih.gov/pubmed/25854781

9. AR.Abdul Aziz. et al. (2014). Survey To See The Impact Of 5s Implementation among Staff of Kpj Seremban Specialist Hospital, Malaysia. Dipetik Maret 12, 2017. Dari http://www.iosrjournals.org/iosr jbm/papers/Vol16issue3/Version-1/L016318296.pdf

10. Osada, T. (2011). Sikap Kerja 5S. Jakarta: PPM

11. Kristianto. (1995). Budaya Organisasi yang Positif. Jakarta: Airlangga

12. Marko Djapan. et al (2016). Lean Thinking in Healthcare: Review of Implementation Results. Dipetik Juni 17, 2017. Dari http://www.ijqr.net/journal/v10-n1/12.pdf 
13. Esain, A., Williams, S., \& Massey, L. (2008). Combining 15. Jay R Patwa. et al (2015). Assessment of planned and emergent change in a healthcare lean transformation. Public Money and Management, 28, 21-6. Implementation of $5 S$ in phc of ahmedabad. Dipetik Juni 17, 2017.2 Dari

14. Amasaka, K. (2015). Constructing A New Japanese http://www.allresearchjournal.com/archives/2015/vol1 Development Design Model - Intellectual Evolution of issue9/PartG/1-9-55.pdf an Automobile Product Design. TEM Journal, 4(4), 336-345. 